\title{
Entangled Values: Construction of a Global Conception of Australian Indigenous Arts
}

\author{
Geraldine Le Roux \\ University of Bretagne Occidentale (CRBC - EA4451, UMS CNRS 3554) \\ Centre de recherche et de Documentation en Océanie (AMU - CNRS - EHESS, UMR 7308)
}

\begin{abstract}
Ainsi, les acteurs économiques et les acteurs culturels, sans qu'on sache toujours lesquels donnent le la, contribuent indissociablement à la définition et à la hiérarchisation des valeurs artistiques et des réputations des artistes. Le circuit culturel s'impose au marché comme épreuve de vérité. ${ }^{1}$ (Moulin, 1992: 79)
\end{abstract}

$\mathrm{T}$ he integration of Australian Indigenous arts in the field of contemporary art is the fruit of a complex historical process deeply rooted in social and political relationships. The Aboriginal art market has grown exponentially since the 90s and acrylic paintings and bark paintings have become international icons of Australian national identity. Aboriginal art has been, and to a certain extent, is still endangered by cheap imitations, fakes and the transgression of Indigenous artists' rights and community protocols. These issues have been addressed by various inquiries and reports since the 1990s. Recently, a new paradigm has emerged from the scholarship produced by researchers, such as Howard Morphy (2000), Jon Altman (2005) and others. These scholars have investigated particularly the communitycontrolled art centres and outlined how it could be taken as a business model. In their studies, the art centres are presented as inter-cultural institutions, as both a commercial and a cultural enterprise in which Indigenous and non-Indigenous people are active agents. With artists, art coordinators, curators, art dealers, bureaucrats, art critics, journalists and visitors who interact to define what Aboriginal art is and where and how it should circulate, we could easily consider the Aboriginal art industry as an art world. Drawing on Danto's work, Howard Becker (1982) describes the art world as "the network of people whose cooperative activity, organized via their joint knowledge of conventional means of doing things, produce(s) the kind of art works that art world is noted for". What evaluative processes do they use to construct and justify their choices? This "loose network of overlapping subcultures held together by a belief in art" (Thornton, 2008) is a challenging site to explore the process of value creation. This paper is focused on the marketing side because this field reveals significant power relations within the Australia's Indigenous arts sector, power relations that conduct to the construction and negotiation of a complex regime of entangled values.

Reports and academic researches often make reference to France in regard to the exportation of Aboriginal art works, probably because of its historical role in the history of arts. But often key information is missing in these reviews, such as important non-commercial exhibitions or

\footnotetext{
1“Therefore, economic actors and cultural actors, without us knowing exactly which ones give the 'la', contribute to the definition and prioritization of artistic values and artist's reputation. The cultural circuit imposes itself to the market as a of truth test'. Author's translation.
} 
cultural events, particularly events that took place outside Paris. With an overview of the structure and visions of the Aboriginal art market, I will address the values that consciously or unconsciously motivate this incomplete assessment ${ }^{2}$. Most of the art dealers who are based in France prefer to work predominantly with community-based artists, mainly from the Northern Territory. Observing the impact of this economic rationality on the representation of Aboriginal culture I aim to analyse how art dealers discuss and locate value differences within or between the economic and cultural domains. This will lead me to address the economic, social and cultural potentialities of a better collaboration between the academic world and the private and public sectors.

\section{Structure and Visions of the Aboriginal Art Market in France}

Aboriginal art came to be represented in France in the 80s with the opening of two major exhibitions Magiciens de la terre (1988) and L'été australien à Montpellier (1990). Baudoin Lebon Gallery was the first art dealer to open, inviting the anthropologist Barbara Glowczewski to curate an exhibition of Warlpiri acrylic paintings. After the success of this exhibition, he continued to work occasionally with Australian Indigenous artists, such as the two recipients of Moet and Chandon Prize, Judy Watson and Gordon Bennett. In 1996, two other Aboriginal art galleries opened. Stéphane Jacob established his company Arts

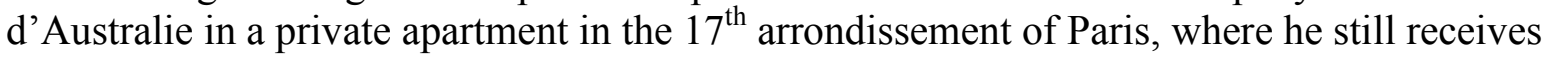
visitors on request. He has always promoted Aboriginal and non-Aboriginal artists and has worked extensively to establish partnerships with museums, which lead him to become a key player in the industry. The dealer, former import-export executive Marc Yvonnou, also opened his gallery in 1996-97. Le Temps du Rêve (Dream Time Gallery) is located in in the small village of Pont-Aven, Paul Gauguin's hometown. In the 90s, another art lover promoted Aboriginal art: Alain Serval exhibited several times his collection of desert acrylic paintings and bark paintings that he has built over the years and during his trips in the far North Australia. As he is not always acting as a full-time art dealer, he occupies a particular place in the Aboriginal art market, at the border between the art lover and the business entrepreneur.

After the introduction of so-called 'tribal arts' (arts premiers) into the Pavilion of the Louvre in 2000, new actors get involved in the Aboriginal art business in France. Morteza Esmaili, an Iranian didgeridoo player, founded the Yapa Gallery in the heart of Paris. Alison Dalbis opened the Dad Gallery in the Parisian suburb of Mantes-la-Jolie. Then, in 2006, the year of the Musee du quai Branly's opening, another step was taken: the Australian gallery Indigenart started collaboration with Mary Durack with the intention of creating a store of several hundred works in Paris. The Australian commercial art gallery Lauraine Diggins Fine Arts rented a space at the Paris Art Fair at Grand Palais. African Muse Gallery, Luc Berthier's tribal art gallery, widened its scope to include Aboriginal art, first by receiving works selected by Marc Yvonnou, then by developing its own partnerships with Arnhem Land art centres. On all these initiatives that have been conducted in the Musée du quai Branly's wave, only two of them have maintained their business and are still active today. Since them, new actors have appeared on the scene, which reveals a strong turn-over. If we concentrate solely on the exhibitions organisation and the pedagogical dimension (meaning art dealers participating at public talks and publishing articles and/or interviews), we count five art dealers that are major actors in the Aboriginal art market in France. Most of them are the historical founders of this market.

\footnotetext{
${ }^{2}$ The field research that undergirds many of the data presented here was carried between 2005 and 2010 both in Australia and France. This article offers a perspective on the art market grounded in that specific period.
} 
Most of these professionals regularly publish brochures, exhibition catalogues or coffee-table books. The majority of their texts discuss Aboriginal art in relatively well-referenced terms, presenting it as a practice defined by Indigenous rights and social obligations. Despite the fact that they share a similar commercial strategy which is to organise and participate at educational activities they have different visions of the Aboriginal art world. I am analysing these viewpoints in regards to field data I have collected over the years while I attended their events. It is interesting to note that their own life experience colours their commercial strategies. One of them, who has a classical training at the Ecole du Louvre, highlights the aesthetic value: his arguments often lie on notions of technics, sense of composition and colours. Two other art dealers emphasise their own career as artists who have lived and worked with Indigenous artists, their way of life becoming the argument for the authenticity of the works presented. Highlighting their experience of living in remote communities, they define themselves as initiated people, using for example the kinship name to suggest that they have been adopted by an Indigenous family. The integration of biographic elements in publications and conferences is a strategy used by many art dealers to attempt to make public the private world of art production, yet they isolate the privacy of commercial negotiations. The potential buyer is being given the possibility to live this experience through the buying act. But as I will show now this strategy conducts some of the art dealers to emphasize certain values and suppress others. The third art dealer who doesn't have the argument of the life experiences neither the diplomas has shifted the focus on the value of the exoticism. How does he publicly acknowledge Indigenous values while he is in fact introducing opposite values that mainly serve his economic interests? I will address this question in two parts, focusing firstly on the carpetbagging issue, and secondly on the death value.

\section{Manipulation of Value Systems}

Like most of his colleagues in France, this art dealer - we'll call him Mr Piront - only works with community-based artists, mainly from Central Desert and Arnhem Land. He has a small gallery in the French countryside but he organises exhibitions and conferences in the whole country. His descriptions of the painting emphasise Dreamtime stories. This notion has been widely analysed in social sciences but the art dealer presents it as a fixed law from ancient times. He doesn't acknowledge its continuing reinterpretation according historical events and social needs by the Indigenous groups; neither doesn't he show that contemporary arts are influenced by various experiences conducted by elders in the context of both colonial and post-colonial encounter. This art dealer uses basic anthropological notions to create a sense of exoticism, not to reveal the values that artists want to share with the non-Indigenous viewers. But the books that sit on his gallery's shelves still make strong impression for the nonspecialist visitors who will see him as an "expert" and an "art lover" who cares for Indigenous artists and their communities. These educations activities lead the art dealers to assert their reputation even if their actions are not always in line with what most Indigenous artists recommend.

People who made submissions to the Contemporary Visual Art Inquiry led by Rupert Myer (2001-2), and later to the Senate Inquiry into Australia's Indigenous Visual Arts and Craft Sector (2006) have shown that many carpetbaggers practice unfair prices such as paying with alcohol or second-hand cars. In Australia, the term carpetbagger designates an intermediary who has unethical practices, a person who bypasses relations with art cooperatives and negotiates directly with Aboriginal artists. The Contemporary Visual Arts and Crafts Inquiry (2002), known as the Myer Inquiry, was commissioned in 2001 by the Minister for the Arts to 
"identify key issues impacting on the future sustainability, development and promotion of the visual arts and crafts sector". Amongst the recommendations, it was stated that the Federal Government should undertake comprehensive research into the needs of the Indigenous visual arts and craft sector. Following this recommendation, the Senate established in 2006 a Committee of Inquiry into Australia's Indigenous visual arts and crafts sector, with particular reference to its current size and scale, the economic, social and cultural benefits of the sector, the needs in infrastructure and the opportunities for strategies that the sector could adopt to improve its practices, capacity and sustainability, including dealing with unethical conduct. In June 2007 the Senate Standing Committee on Environment, Communications, Information Technology and the Arts completed its report Indigenous Art, Securing the Future: Australia's Indigenous visual arts and craft sector.

These reports indicate that the most unscrupulous carpetbaggers attempt to disconnect the artists from their communities, inviting them to paint in cities, in hotel rooms or in backyards. By isolating the artists for a few days, they can influence them to paint specific stories, patterns and styles, in particular those which are most popular on the market. In so doing, they encourage artists to neglect the protocols of Aboriginal Law, the channel through which these patterns, in accordance with specific rights and social obligations, are passed down from the ancestral beings. Carpetbaggers neglect the specificities of this form of cultural transmission and cooperation, influencing artists to produce what consumers expect and to paint collectively with whoever is available. Songs and other stories cannot be shared in such a context of industrial production. As many analyses focused on arts centres show (Morphy and Wright, 2000; Altman, 2005), while art centres primarily seek to manage the artists' interests to the best of their ability, investing in equipment, developing exhibitions, and initiating cultural projects for the centre, carpetbaggers encourage fast art, the hurried production of works. They encourage prestigious artists to paint for a meagre sum, and persuade talentless artists to copy highly valued works. Borrowing Raymonde Moulin's expression (1992), I call these works 'paintings by the dozen', an expression that emphasises the notion of reproduction.

Carpetbaggers exert pressures on Indigenous people to encourage a process of production rather than creation, reproduction over the creative act. As Raymonde Moulin showed it (1978), in Montmartre and other touristic sites visitors can find seascape and rural landscape paintings inspired by European masters from previous centuries. Both these works appeal to foreign purchasers who want to buy what they believe a piece of art for a relatively moderate price. The art dealers who sell such products must develop a discourse that serves to reassure their clientele. Instead of notions of style and quality, art dealers emphasize the Indigenous origins of the artist. Their labels indicate the name of the artist, his/her kinship name, the birthplace, their clan-affiliation and Indigenous language(s). These are indeed important indexes of the artist's identity and most of the Australian Indigenous artists wish to see them transmitted. But in some art dealers' discourses, these indexes that express intimate connexions with the land are entangled in another process of value creation: their singularity is used to express exoticism and rarity. Indigenous values are carefully selected by the art dealers to fit with the Western representation of uniqueness, which is indeed what the art world always looks for. But if some art dealers do it in a subtle way, combining the aesthetic value with the value of singularity, other express it solely within the parameters of the exoticism, even pushing it toward the myth of the disappearing Indigenous society.

With the international boom of the Aboriginal art market in the 2000 and later with the increasing number of scandals, French art dealers have modified some of their strategies. I 
will not comment on strategies of denigration and rumours used by art dealers - as this is common to any art market. I would rather explore further the creation value process. Because the debate is largely controlled by art dealers who are scared to bring these issues into the public sphere, most Aboriginal art potential buyers in France were not aware of the issues of cheap imitations, fakes and artists' exploitation. This left the art dealers free to manipulate the audience for their own benefits and, sometimes, at the expense of Indigenous people's expectations. As I previously said, the art dealer Mr Piront regularly organises commercial exhibitions and public talks during which he not only promotes secondary-quality works but diffuses broadly stereotyped discourses on Aboriginal art and culture. He speaks about the fast disappearance of the culture and denies Indigenous agency. Many Aboriginal artists are aware of the feeble amount of money carpetbaggers pay them, self-consciously creating poorquality paintings in return. The famous painter Emily Kame Kngwarreye has commented several times on this strategy of producing bad quality paintings for bad people.

For a long time, this situation had never been addressed publically by any art dealers in France. But with the increasingly publication of reports and articles in popular newspapers and their publication online, French art dealers had to address the issue of unethical practices. One of them started to comment much more on the function of the art centres, describing it as a site which unites social networks, and guarantees cultural transmission. He often describes the degrading living conditions of many Aboriginal people, in contrast to the way the artistic cooperative system pays artists fairly. The connection made by him between the bad living conditions of Aboriginal people and the utility of the art presents the buying act as attractive. It is either a way of injecting money into remote communities either a way of participating to the "Closing the gap" campaign. This strategy built on the ethics of the fair trade is diametrically opposed to the views of another dealer, who blatantly demands the right to refuse to work with art centres. According to him, the recommendations made by DESART and ANKAAA do not further the interests of artists who must be allowed to produce as much as they want and sell their works for the price they want. These arguments are reminiscent of those voiced in the Australian journalist Robert Nelson's response to the questions raised by Nicolas Rothwell. To a certain extent, we could say that Mr Piront uses notions of both dysfunctionality (cf. Garond this volume) and sovereignty to free the artist from any support that could constraints his own business, an hypothesis that I am exploring now.

In the value creative process, the notion of rarity is essential. Death has always been central to the art word, manifesting a paradox: it is the death of a man that many admire as well as a new journey for the ones who have been collecting his work. As an observation illustrates it, it is not different in the Aboriginal art world: in 2006 was published a coffee-table book, a catalogue entitled Art of Utopia. It showed a photo of Emily Kame Kngwarreye's grave with the legend stating «the story continues... ». The second line indicates the gallery's website. Some art dealers establish a parallel between the death of the artist and the death of the culture. They play on both the individual's death and the symbolic dimension to it, which is the disappearance of the Indigenous culture. Mr Piront comments widely on a so-called lack of interest of the youth for the initiation process and for Indigenous values. As other art dealers, he also emphasises the problem of alcoholism and violence. The reference to this 'dysfunctionality' helps them to emphasise the fact that "their" artists are the last ones able to paint "authentic" stories, which makes of them a good investment. This vision does not only represent Aboriginal society as a dying society, it also leads to a dangerous process of preconceiving what Aboriginal art should be at the exclusion of other experimental forms. This context must be taken into account when considering urban artists' critiques of this 
system, their desire to break with the idea of a presumed authenticity and with the predicted death of a culture (Le Roux, 2012; Riphagen, 2013).

It is also interesting to note that some of the art dealers who seem to have high ethics have in reality doubtful practices. They dare editing the story that goes with the certificate of authenticity in order to make the painting looks more "Aboriginal". They substitute themselves to the artist choosing how the painting should be explained. Experts know that art centres coordinators do it sometimes, but it is done under the supervision of the artist and his/her prior agreement. Art dealers who edit the story are manipulating an important cultural value to encourage sells. Whereas the Dreamtime story is seen by potential buyers as an index of authenticity, it is in reality the effect of an intercultural relations in which power relations change over the time. At the end of the commodity's chain, when the artwork has left the community, the art dealer has the capacity to manipulate each index. This power relation around values is also seen in the promotional choices made by art dealers: when they promote the buying act as an ethical action that promotes Indigenous sovereignty, they don't mention that they only support some artists and not the ones who don't fit with the popular vision of Aboriginality. Mr Piront's public statements clearly show how the Aboriginal arts exploitation system works. But as we have seen, it is a far more complex process of creation values which entangles aesthetic, political, economic and social values.

\section{The Value of Knowledge}

Since the beginning of the 21th century, the pre-eminent policy and funding role of the Australia Council has diminished with the expansion of programs and funds managed by the Department of Foreign Affairs and Trade and new state and territory arts funding authorities. As Fred Myers highlighted it in the 1990s Aboriginal culture became « increasingly, the source of Australia's self-marketing for the international tourist industry, the 'difference' they have to offer ». (Myers, 1991: 53). Indeed, Aboriginal art became the basement of a multimillions industry and its international exports are worth several millions of dollars. The Myer inquiry and posterior surveys that aimed to address the economic, social and cultural benefits of the Australia's Indigenous arts sector have pointed out the need to further developing international markets. These reports mainly frame the promotion of Aboriginal arts in terms of business opportunities. One of them stated that the public sector is less skilled in the area of international cultural trade than the commercial sector. What are the effects and limits of this economic vision of the art industry?

Austrade is the Australian Government's export and international business facilitation agency and provides access to overseas markets through export market development grants. In their submission to the Senate Committee of Inquiry into Australia's Indigenous visual arts and crafts sector, Austrade provided a list of seven Indigenous art export initiatives that were held in France in the year 2006. This number is incorrect and amongst the missing events, some of them have been conducted by art dealers and another was an exhibition supported by the Australian Embassy's fund. If most reports have a good understanding of the complexity of the Aboriginal art production chain and its circulation within the national territory, their knowledge of the distribution of Aboriginal art overseas, and in particular in France, isn't as relevant. Some of these reports recommend that art dealers should benefit more from public funds: they argue that with their knowledge of the art world and their networking capability art dealers would increase Aboriginal art sales overseas. Of course artists and art centres need sells and these sells are the result of strategies developed in partnerships with art dealers and other cultural intermediaries. But if policies makers don't always have a big picture of the art 
international circulation chain - this could be partly due to the loss of corporate and expert knowledge within the bureaucracy - how can they select the art dealers who will receive the funds? Furthermore, the artistic promotion developed by art dealers is motivated by economic choices. The economic rationality influences art dealers to promote certain styles, mainly the ones created by community-based artists, influencing in return the representation of Australian Indigenous cultures overseas.

Undertaken in response to reports of unethical treatment of Indigenous artists, the Indigenous Australian Art Commercial Code of Conduct was established in 2010 and is now institutionalised. It represents the commitment of individuals and organisations across the Indigenous visual arts industry to put an end to exploitative practices which take advantage of artists and negatively affect their communities. The code specifically addresses the notion of the fair payment and the transparency of the negotiation process. The Australian Embassy's website in France draws attention to the Indigenous Australian Art Commercial Code of Conduct. On this website it is stated that members of the Indigenous Australian arts industry are expected to have signed-up to the Code by early 2010, after which the Embassy will give preference to working with Australian commercial entities that are signatories to the Code. The art dealer referred in my paper as Mr Piront was until mid-2013 in the list of art dealers indicated by the Embassy under the previous statement although he is not a signatory of the Code. What I am suggesting with that fieldwork observation is that the analyses on the values of the art industry must deal with a flux of practices that are motivated by different values systems. Reports written in Australia reveal a good understanding of the complexity of the Aboriginal art production chain and its circulation within the national territory but their representation of the international network and how Aboriginal art arrives in France isn't accurate. Some might object that bureaucrats take such reports as indicators of a tendency and not as exhaustive surveys. But with regard to how the sector operates, these reports are actually both symbolic of the dominance of the financial value over the cultural exchange value and vehicles for its reproduction. There are indeed many more export opportunities in France than the ones suggested in the Australian reports. There are several museums with historical and contemporary Aboriginal art collections and many other non-profit associations who are willing to foster their relations with Aboriginal Australia. But because these agents don't have the same visibility and the same power to mobilize public funds, there are made invisible in reports. As we know in the field of social sciences, interactions between the art market, public institutions and the civil society can be beneficial, with an increase of knowledge and art sales in return. Artists frequently acknowledge small-independent projects and recognize the values of alternative models of education and art dialogue as a critical counterweight to the expensive art fairs and biennales. In regard to the French export market, it could be interesting to see how Aboriginal artists value these alternative events in regard to the more-traditional commercial exchange setting ${ }^{3}$.

In the process of art commodification, cultural intermediaries play with different values systems to justify their choices and build a highly-valued object. But in the context of the Aboriginal art industry carpetbaggers do not only create values, they impose norms to artists: they influence them to adapt their artistic practices to the neo-liberal work model: they sometime put them in a restricted space, where they will not be bothered by other people's requests; they ask them to paint certain stories, and they also encourage them to share the labour with whoever is available. In that context, Indigenous values such as the transmission

\footnotetext{
${ }^{3}$ I am currently conducting a survey of the events organised and sponsored by the Australian Embassy in Paris since the 70's.
} 
potentiality are partly suppressed from the production sphere. Following another commercial strategy, some art dealers and art writers try to remain silent on the increase in fakes and works of poor quality, rendering Aboriginal art an authentic product, unaffected by the issues relating to markets. In other words, they hide from the visitors' eyes Indigenous agency and how artists, individually or collectively, are engaging with different value systems.

\section{Works Cited}

Altman, Jon and Taylor, Luke. "Too Many Dreamings: Diversity and Change in bark paintings from west Arnhem." C Chubb and Sever N, eds. Indigenous Art at the Australian National University. Melbourne: Palgrave Macmillan, 2009.

Altman, Jon and Taylor, Luke. Marketing Aboriginal Art in the 1990s, Canberra: Aboriginal Studies Press, 1990.

Altman, Jon. "Brokering Aboriginal Art: A Critical Perspective on Marketing, Institutions and the State." Geelong: Deakin University, 2005.

Glowczewski, Barbara. Rêves en Colère. Alliances aborigènes dans le Nord-Ouest australien. Paris : Plon, 2004.

Le Roux, Géraldine. "Regards d'artistes sur les processus de patrimonialisation et de commercialisation de la culture aborigène." Journal de la Société des Océanistes, 134 (2012) : 55-64.

- $\quad$ Création, réception et circulation internationale des arts aborigènes. Ethnographie impliquée et multi-située avec des artistes de la côte est d'Australie. EHESS Paris \& University of Queensland, PhD thesis, 2010.

Morphy, Howard and Wright, France, eds. The Art and Craft Centre Story: A Survey of Thirty-nine Aboriginal Community Art and Craft Centres in Remote Australia. Canberra: Wooden publisher, 2000.

Morphy, Howard. Becoming Art. Exploring Cross-Cultural Categories. Sydney: University of New South Wales Press, 2008.

Moulin, Raymonde. L'artiste, l'institution et le marché. Paris : Flammarion, 1992.

Le marché de la peinture en France. Paris : Minuit, [1967] 2000.

Myers, Fred. Painting Culture: The Making of an Aboriginal High Art. Durham: Duke University Press, 2002.

Pintupi Country, Pintupi Self. Sentiment, Place and Politics among Western Desert Aborigines. Washington D.C. : Smithsonian Institution Press, 1991.

Myer, Rupert. Report of the Contemporary Visual Arts and Craft Inquiry (The 'Myer Report'). Canberra: Dept. of Communications, Information Technology and the Arts, 2002:

Riphagen, Marianne. "Contested Categories: Brook Andrew, Christian Thompson and the 
etropic 13.2 (2014): Value, Transvaluation and Globalization Special Issue | 83

Framing of Contemporary Australian Art." Australian Humanities Review, vol. 55, no. 2013(2013): 93-118.

Rothwell, Nicolas. "Scams in the desert." Canberra: The Weekend Australian, 3 March 2006: 3-4. 